\title{
Further investigations on the airborne excretion of foot-and-mouth disease virus
}

\author{
By A. I. DONALDSON,* K. A. J. HERNIMAN, J. PARKER \\ AND R. F. SELLERS \\ Animal Virus Research Institute, Pirbright, Woking, Surrey
}

(Received 22 May 1970)

\begin{abstract}
SUMMARY
Calf thyroid tissue cultures were found to be the most sensitive system in detecting virus collected in a large volume air sampler from boxes, where cattle, sheep and pigs infected with $A$ and $C$ strains of foot-and-mouth disease (FMD) virus were housed. It was confirmed with all strains of FMD virus tested that pigs excreted the most virus followed by cattle and sheep, but there was variation between strains, the highest virus recoveries being obtained from animals infected with $\mathrm{O}_{1}$ and $\mathrm{C}$ Noville viruses. The results are discussed in relation to outbreaks of foot-and-mouth disease in Great Britain since 1954.
\end{abstract}

\section{INTRODUCTION}

The airborne excretion of four strains of type O FMD virus from cattle, sheep and pigs has been reported by Sellers \& Parker (1969). In the present paper these investigations have been extended to include measurement of virus excreted by animals infected with other types and subtypes of foot-and-mouth disease.

\section{Virus}

\section{MATERIALS AND METHODS}

Two strains of FMD virus type A ( $A_{22}$, Iraq $24 / 26 ; A_{5}$ Eystrup (Tübingen)) and two strains of type $\mathrm{C}$ (C Lebanon $3 / 69$; C Noville) were used. They had been passaged in cattle apart from C Lebanon, which had been passaged once in IBRS-2 cells (de Castro, 1964). The $\mathrm{O}_{1}$ and $\mathrm{O}_{2}$ strains of FMD virus shown in the Tables 1 and 5 had been passaged in cattle and pigs respectively.

\section{Virus assay}

The stock preparations of the virus strains were assayed by inoculating serial dilutions into unweaned mice (Skinner, 1951) and the following tissue culture systems maintained as monolayers in tubes: calf thyroid, BHK 21 Clone 13, IB-RS-2, primary guinea-pig kidney and calf kidney. In the first experiments air samples were assayed in these systems and also in monolayers in bottles up to the size of Roux bottles. In later experiments only calf thyroid tubes and unweaned mice were used.

* Visiting fellow, Canædian Medical Research Council. 


\section{Infection of animals}

The breeds and weights of the animals used have previously been described (Sellers \& Parker, 1969). Sheep and pigs were inoculated subcutaneously on the coronary band and on the bulbs of the heel of one foot, respectively. Cattle were inoculated intradermally at four sites on the tongue. In one experiment $\left(A_{22}\right)$ cattle were exposed to infection by being held in an isolation unit containing diseased pigs. In another experiment $\left(A_{22}\right)$ cattle were inoculated intramuscularly. The dose of virus employed in all cases was from $10^{5}$ to $10^{6}$ TCD 50 .

Air sampling was carried out as previously described (Sellers \& Parker, 1969); the animals were examined daily and the extent of lesions recorded.

\section{RESULTS}

\section{Comparative titres of stock preparations and of aerosol samples}

The titres of the various virus stocks are shown in Table 1. It can be seen that calf thyroid tissue culture was the most sensitive system for virus detection. In a series of air samples tested in calf thyroid cultures and in mice, calf thyroid cultures gave a higher titre than mice on 33 out of 42 occasions. In addition minimal

Table 1. Titres of different strains of FMD virus in various assay systems

Virus strains

\begin{tabular}{|c|c|c|c|c|c|c|}
\hline Assay system & $\mathrm{O}_{1}$ BFS 1860 & $\mathrm{O}_{2}$ Brescia & $\mathbf{A}_{\mathbf{5}}$ Eystrup & $A_{22}$ Iraq & C Lebanon & C Noville \\
\hline Calf thyroid & $7 \cdot 7^{*}$ & $6 \cdot 5$ & $7 \cdot 1$ & $7 \cdot 1$ & $8 \cdot 1$ & $8 \cdot 3$ \\
\hline BHK 21 & $4 \cdot 4$ & $4 \cdot 3$ & $2 \cdot 84$ & $4 \cdot 5$ & $6 \cdot 1$ & $2 \cdot 1$ \\
\hline IB-RS-2 & 4.95 & $4 \cdot 45$ & $2 \cdot 49$ & $5 \cdot 1$ & $6 \cdot 6$ & $4 \cdot 3$ \\
\hline $\begin{array}{l}\text { Guinea-pig } \\
\text { kidney }\end{array}$ & $5 \cdot 9$ & $5 \cdot 53$ & $5 \cdot 15$ & $6 \cdot 6$ & $7 \cdot 5$ & 7.05 \\
\hline Calf kidney & $6 \cdot 1$ & $5 \cdot 1$ & $5 \cdot 7$ & $5 \cdot 5$ & $7 \cdot 2$ & $7 \cdot 55$ \\
\hline Unweaned mice & $7 \cdot 5$ & $6 \cdot 5$ & $4 \cdot 8$ & $6 \cdot 9$ & $7 \cdot 5$ & $7 \cdot 6$ \\
\hline
\end{tabular}

amounts of virus were detected in 20 samples, which were negative in mice, the reverse occurring in only two samples. In some instances the failure to detect or the lower titres in calf thyroid cultures could be attributed to contamination after the first day. With $A_{5}$ virus calf kidneys were the most sensitive in some assays of aerosol samples and with C Lebanon (IB-RS-2 passage) on one occasion higher titres were found in BHK and IB-RS-2 cells than in calf thyroids. Otherwise calf thyroid cultures were more sensitive than BHK 21, IB-RS-2, guinea-pig kidney and calf kidney cultures, and only calf thyroid cultures together with mice were used in the later experiments.

\section{Operation of large volume air sampler}

To find the collecting fluid giving maximum virus recoveries the following fluids were compared during sampling of virus from infected pigs: phosphate buffered saline (PBS) containing 5\% heat inactivated ox serum; PBS containing $0.5 \%$ 


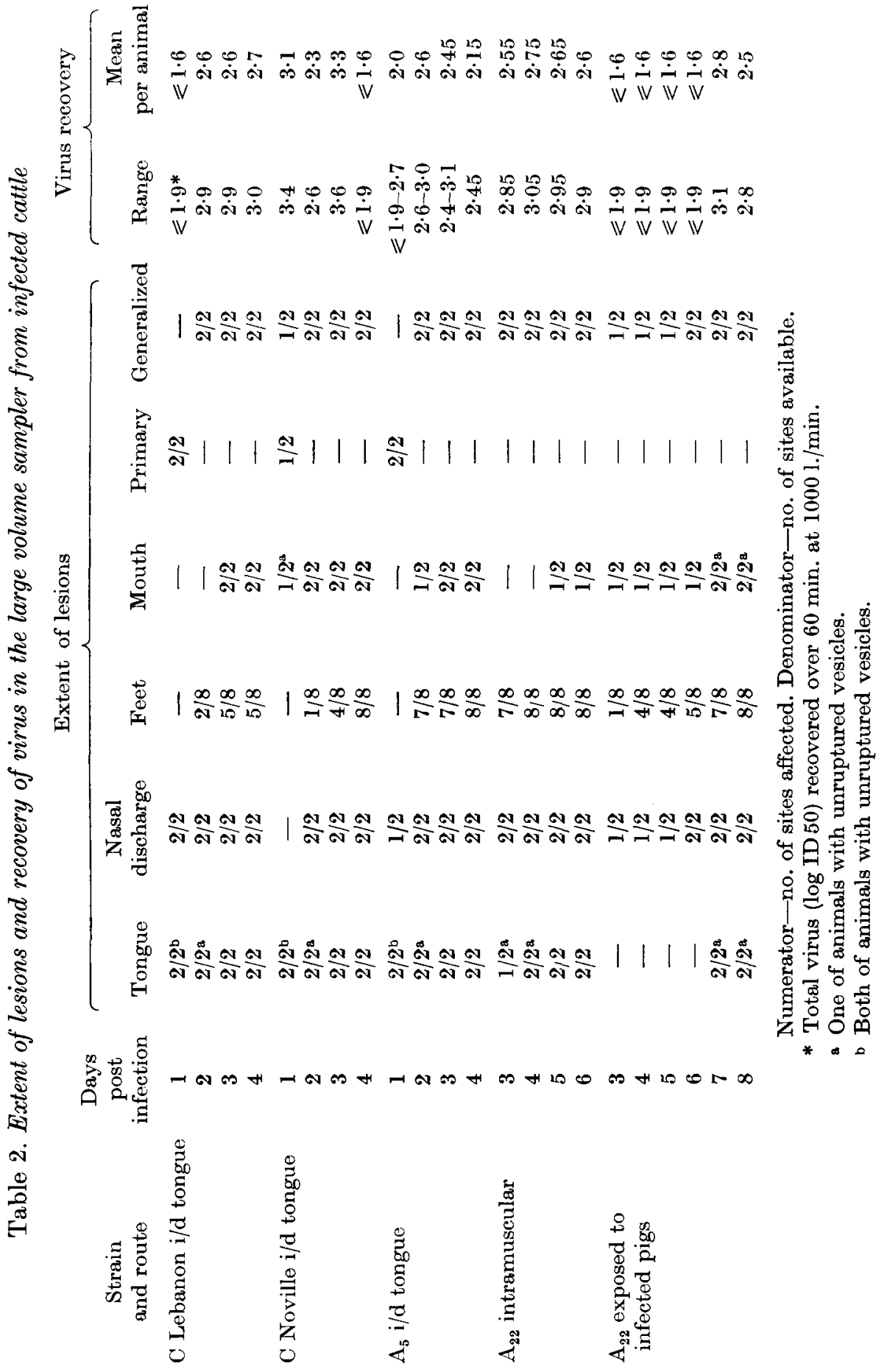




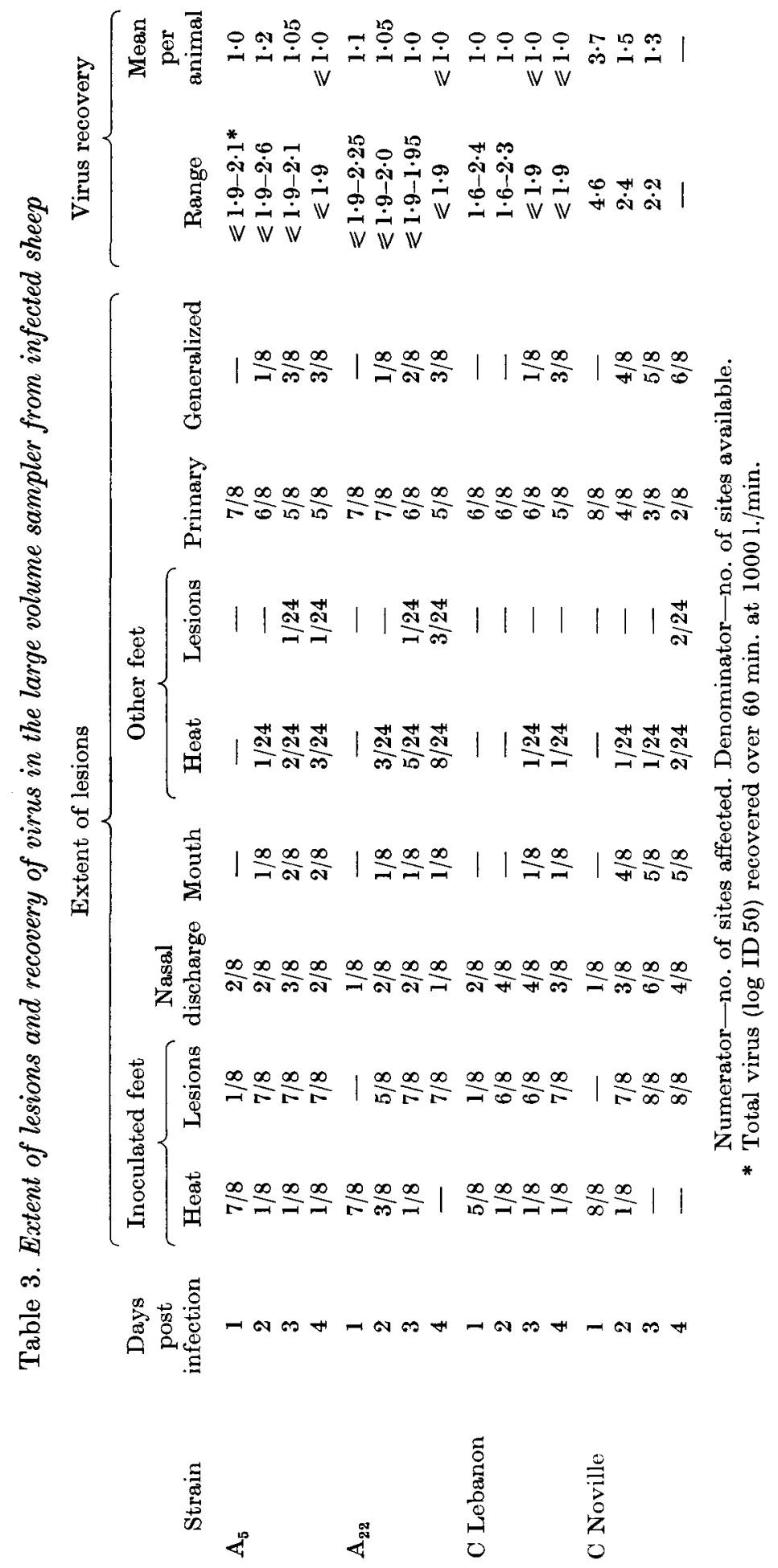




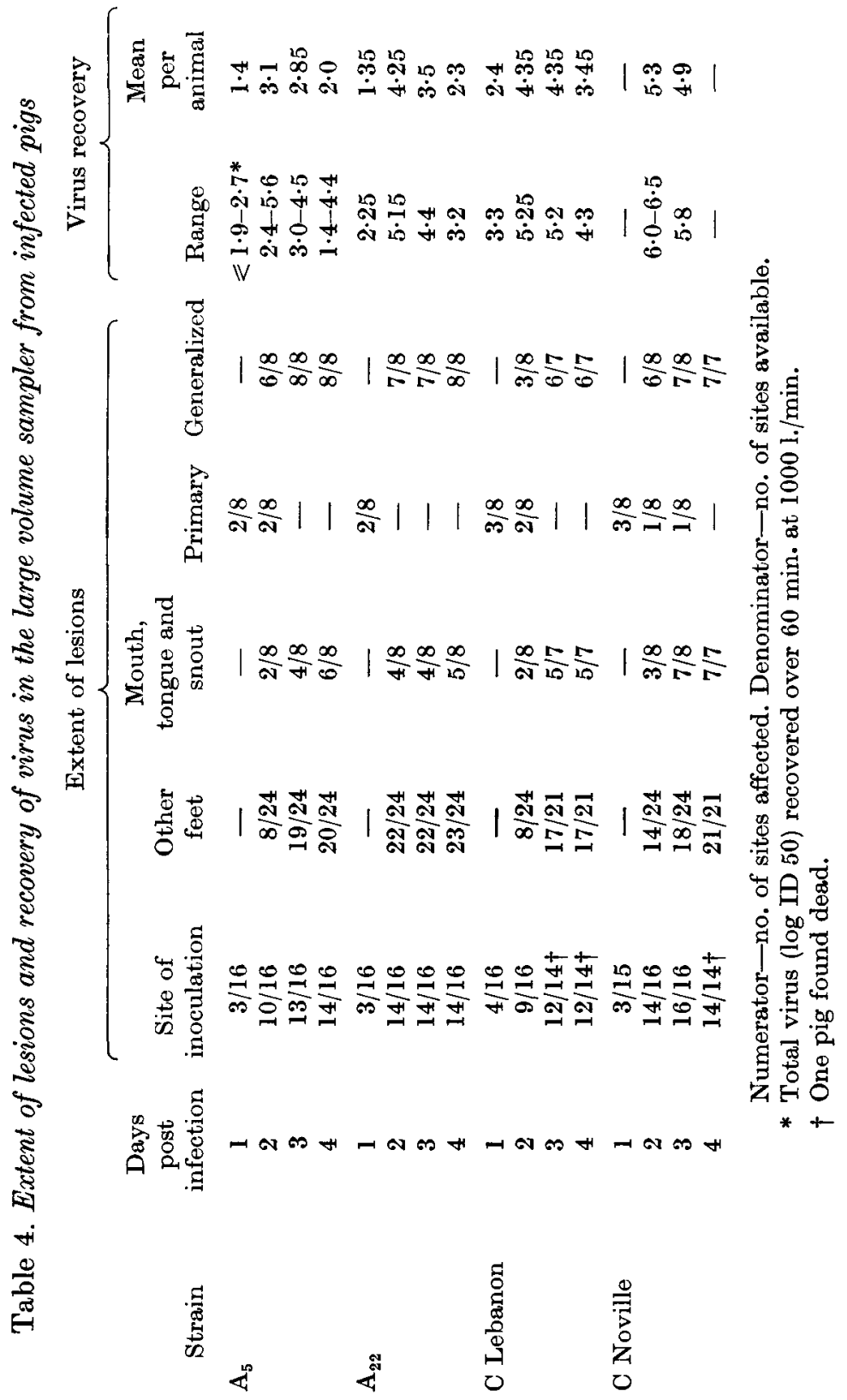


bovine serum albumin; and $\mathrm{m} / 15$ phosphate buffer $\mathrm{pH} 7.2$ containing $1 \%$ heat inactivated ox serum. The highest recoveries, although only by a factor of $0.2-$ $0.5 \log$ units, were obtained using $\mathrm{M} / 15$ phosphate buffer and $1 \%$ inactivated ox serum, and this collecting fluid was routinely employed.

\section{Sampling of infected animals}

The results of sampling the air in loose boxes containing cattle infected with different strains of FMD virus are shown in Table 2. Maximum recoveries were obtained when generalization of lesions was observed regardless of the initial method of exposure. In general the lowest amount of virus was recovered from animals infected with $A_{5}$ virus but apparently no detectable virus was recovered from one of the cattle exposed to $A_{22}$ infected pigs. A feature of the clinical response was the occurrence of a serous nasal discharge at the time of primary lesions; later the discharge became more viscid and mucopurulent leaving encrustations on the nasal orifices. The development of other lesions is shown in Table 2.

With sheep (Table 3 ) the maximum amount of virus was found during the first $36 \mathrm{hr}$. after exposure, i.e. before lesions resulting from generalization were seen. Apart from the experiment in which $\mathrm{C}$ Noville was used, the mean recoveries per animal were lower than those obtained from cattle. Generalized lesions were not frequently observed; when they were, lesions on the dental pad were most common. An early serous nasal discharge was often observed.

Virus recoveries obtained in loose boxes containing pigs are shown in Table 4. As with cattle, maximum excretion occurred at the time of generalization. Little virus was excreted on the first day post inoculation, but on days two and three high levels of virus were detected, the virus titre decreasing on the fourth day and later. The extent of lesions is shown in Table 4. Nasal discharge was noted on occasions.

The experiments described here took place from May 1969 to March 1970 during spring, summer, autumn and winter and the temperature varied from 8.9 to $30^{\circ} \mathrm{C}$. There was no apparent difference in the amount of virus recovered at the different times of the year. Relative humidity was consistently maintained above $70 \%$.

\section{Maximum amount of virus recovered}

The maximum amount of virus recovered for each strain and species, the extent of the lesions and the time after exposure are shown in Table 5. This also includes results obtained on other occasions with $\mathrm{O}_{1}$ and $\mathrm{O}_{2}$ strains of virus. In the last column the amounts are added together for comparison between strains.

\section{DISCUSSION}

Snowdon (1966) showed that the titres of unmodified cattle virus were on the average 30 -fold higher in calf thyroid cultures than in other assay systems and in our experiments airborne FMD virus was recovered most consistently in calf thyroid cultures. Comparisons of the results obtained with different strains of virus is, therefore, based on the use of the most sensitive method of detection.

With all the strains the highest yield of virus was obtained from infected pigs, although there were variations between the amounts with the different strains, 
the most coming from pigs infected with $\mathrm{C}$ Noville, $\mathrm{O}_{1}$ and $\mathrm{O}_{2}$. Less virus was detected in the collections from sheep and cattle, especially those inoculated with $\mathrm{O}_{2}, \mathrm{~A}_{5}, \mathrm{~A}_{22}$ and $\mathrm{C}$ Lebanon strains. It is not certain whether the variation between strains in the amounts recovered is due to better survival in air or to greater excretion from the animal, but the second reason is more probable owing to the close proximity to the animals of the collecting apparatus and the results obtained from detection of virus in the nose (Sellers, Donaldson \& Herniman, 1970). When the log maximum titres are added together it is apparent that the greatest amount of virus was recovered from animals infected with the $\mathrm{O}_{1}$ and $\mathrm{C}$ Noville strains.

Table 5. Maximum amount of virus collected per animal, time and extent of lesions in animals infected with strains of FMD

\begin{tabular}{|c|c|c|c|c|c|c|c|}
\hline \multirow[b]{2}{*}{ Strain } & \multicolumn{2}{|c|}{ Cattle } & \multicolumn{2}{|c|}{ Sheep } & \multicolumn{2}{|c|}{ Pigs } & \multirow[b]{2}{*}{$\begin{array}{c}\text { Total } \\
\text { virus } \\
\text { collected }\end{array}$} \\
\hline & $\begin{array}{l}\text { Maximum } \\
\text { virus }\end{array}$ & $\begin{array}{l}\text { Time and } \\
\text { extent of } \\
\text { lesions } \\
\text { (hr.) }\end{array}$ & $\begin{array}{l}\text { Maximum } \\
\text { virus }\end{array}$ & $\begin{array}{l}\text { Time and } \\
\text { extent of } \\
\text { lesions } \\
\text { (hr.) }\end{array}$ & $\begin{array}{l}\text { Maximum } \\
\text { virus }\end{array}$ & $\begin{array}{l}\text { Time and } \\
\text { extent of } \\
\text { lesions } \\
\text { (hr.) }\end{array}$ & \\
\hline$O_{1}$ & $3 \cdot 7^{*}$ & $41, G$ & $3 \cdot 6$ & $24, \mathrm{~N}$ & $5 \cdot 4$ & $45, \mathrm{G}$ & $12 \cdot 7$ \\
\hline $\mathrm{O}_{2}$ & $2 \cdot 5$ & $42, \mathrm{G}$ & $2 \cdot 1$ & $22, \mathrm{~N}$ & 5.1 & $68, \mathrm{G}$ & $9 \cdot 7$ \\
\hline$A_{5}$ & $2 \cdot 8$ & $46, \mathrm{G}$ & $1 \cdot 7$ & $44, \mathbf{P}$ & $4 \cdot 7$ & $48, G$ & $9 \cdot 2$ \\
\hline$A_{22}$ & $2 \cdot 8$ & $70, \mathrm{C}$ & $1 \cdot 35$ & $19, \mathrm{~N}$ & $4 \cdot 25$ & $48, \mathrm{G}$ & $8 \cdot 4$ \\
\hline $\mathrm{C}_{\mathrm{LLBB}}$ & $2 \cdot 7$ & $93, \mathrm{G}$ & $1 \cdot 5$ & $19, \mathrm{~N}$ & $4 \cdot 35$ & $46, \mathrm{G}$ & 8.55 \\
\hline $\mathrm{C}_{\text {xov }}$ & $3 \cdot 3$ & $70, \mathrm{G}$ & $3 \cdot 7$ & $22, \mathrm{~N}$ & $5 \cdot 6$ & $46, \mathrm{G}$ & $12 \cdot 6$ \\
\hline
\end{tabular}

These strains are representative of the most recent epidemics in Europe since 1964, whereas of the other four strains, $A_{22}$ and $C$ Lebanon came from the Near East. It may be that this difference reflects a selection for ability to spread by the airborne route or by animal movement depending on the prevalent climatic conditions. As found previously, maximum virus was detected in pigs and cattle when lesions had generalized, whereas with sheep, apart from $A_{5}$, maximum virus was detected before vesicles appeared. A constant feature was the presence of a nasal discharge, which suggests infection of the upper respiratory tract.

In a previous reference to airborne transmission of virus, sheep were described as acting as maintenance hosts, pigs as amplifiers and cattle as indicators (Sellers \& Parker, 1969). In the light of the results obtained with other strains and types of virus, primary and secondary outbreaks of FMD in Great Britain since 1954 have been examined to determine the role of the various species. It is apparent that the amount of virus released by a species of animal is only one of the factors influencing the degree of airborne spread after an initial outbreak. The numbers of animals involved, the period before the disease is reported as well as the topography of area, the livestock density and the climatic conditions are all important. Out of the 179 primary outbreaks from 1954 to 1967 only 81 spread (Report of Committee of Inquiry Part 2, 1968). Examples of spread attributed to pigs as a primary source were O in Shropshire 1967, Worcestershire 1967, Hampshire 1967, A in Caernarvon 
1957 and Warwickshire 1961 and C in Essex 1956 and the West Riding of Yorkshire 1960. Attributions to cattle as a primary source were found in outbreaks in Somerset 1957 and Northumberland $1966(O)$, Norfolk 1958 and Northumberland 1960 (A) and Buckinghamshire and Wiltshire 1956 (C). Primary outbreaks were rarely attributed to disease in sheep, apart from an 0 outbreak in Gloucestershire (1956) where pigs were also involved. However, in the 1967-68 $O_{1}$ epidemic 29 outbreaks occurred where sheep and cattle were affected at slaughter. In 15 of these the lesions in sheep were described as older, and these sheep could have transmitted the disease to cattle on the same farm. In other instances, on farms where only sheep were affected, outbreaks in cattle nearby could be attributed to spread from the sheep. Examination of spread of disease up to 14 days after primary outbreaks showed that where subsequent outbreaks were attributed to local spread, i.e. wind, movement of wild animals and birds etc., $83 \%$ of outbreaks were in cattle, $14 \%$ in sheep and $3 \%$ in pigs. Assuming that cattle, sheep and pigs are equally at risk, these percentages are higher for cattle and lower for sheep and pigs than might be expected from the numbers of animals involved. However, this distribution would support the suggestion previously made (Sellers \& Parker, 1969) that signs of foot-and-mouth disease might be seen first in cattle since cattle would sample more of the infected air than sheep and pigs and since in cattle the rate of development of lesions is more rapid.

Mr W. G. Parkinson of the Ministry of Agriculture, Tolworth, Surrey, is thanked for his extensive help in supplying information on foot-and-mouth disease outbreaks since 1954. Mr N. S. Needham of the Ministry of Agriculture, Worcester, kindly gave us information on the outbreak in Worcester 1967. We should like to thank Miss C. D. Mills, Miss J. Piper, Miss J. Slater, N. H. Cheale and D. R. Taylor for their technical assistance.

\section{REFERENCES}

De Castro, M. P. (1964). Behaviour of the foot-and-mouth disease virus in cell cultures: susceptibility of the IB.RS-2 line. Archivos do Instituto biológico, São Paulo 31, 63.

Report of the Committee of Inquiry on Foot-and-Mouth Disease 1968 Part 2 (Command 4225 H.M.S.O.).

Sellers, R. F. \& PARKer, J. (1969). Airborne excretion of foot-and-mouth disease virus. Journal of Hygiene 67, 671.

Sellers, R. F., Donaldson, A. I. \& Herniman, K. A. J. (1970). Inhalation, persistence and dispersal of foot-and-mouth disease virus by man. Journal of Hygiene 68, 565 .

SkINNER, H. H. (1951). Propagation of strains of foot-and-mouth disease virus in unweaned white mice. Proceedings of the Royal Society of Medicine 44, 1041.

SNowdon, W. A. (1966). Growth of foot-and-mouth disease virus in monolayer cultures of calf thyroid cells. Nature, London 210, 1079. 